\title{
STRATEGY OF STATE SUPPORT OF AGRICULTURAL ENTERPRISES
}

\section{Kateryna Malinoshevska ${ }^{1}$}

DOI: https://doi.org/10.30525/978-9934-26-077-3-33

Abstract. The purpose of agricultural enterprises is to improve the quality of domestic products, their competitiveness, food security, development of genetics and breeding, reproduction of land fertility, digitalization, which is impossible without economic transformation, management decisions, the introduction of technological processes for the long-term development of agriculture. The agro-industrial complex plays an important role in the development of the economy as a whole and performs a social function, ensures food security of regions and employment of people living in rural areas, so the quality of life depends on the formation of economic development of agriculture. Methodology. A scientific approach to solving problems allows to model possible situations and avoid negative consequences due to incorrect strategic policy of the organization. Construction of a matrix of strategic qualitative analysis based on methodological approaches to assessing the characteristics, properties of enterprise development strategy and implementation of economic development strategies for agricultural enterprises based on the use of analysis, which provides priority identification of strengths and weaknesses, potential opportunities and threats, languages that can be used to formulate the strategy of agricultural enterprises, is an important step in building a strategy. Results. In a competitive market, it is impossible to succeed by providing low-quality services or offering lowquality goods. Before developing business management processes, it is necessary to develop a functional strategy. Strategic analysis, which gives a realistic assessment of their own resources and capabilities in relation to the state and needs of the environment for agricultural enterprises and helps to make a rational choice of strategies from a variety of options. Practical implications. Strategies at any level usually do not have the resources or ability to use resources in a way that provides full confidence in success.

${ }^{1}$ PhD., Financial Director of «Highline Media» Ltd., Ukraine 
Therefore, during the qualitative strategic analysis, in our case, we have determined that the miscalculations in the opening of the land market (no restrictions for buyers, price formation, protection mechanisms against speculative resale of land), war, political and economic crisis in Ukraine, miscalculations in the regulation of the industry, deterioration of land quality, loss of land value due to the development of alternative production, further decline in margins, degradation of the sector, loss of yield potential due to soil degradation resulting from intensive production, raiding, high cash turnover, fraudulent schemes, counterfeiting products, pressure from law enforcement agencies are threats to building an effective strategy for agricultural enterprises, it is necessary to take into account the strengths and weaknesses of agricultural enterprises and on the basis of opportunities to achieve economic growth.

\section{Introduction}

The agro-industrial complex has changed over the years, and our country has become the center of food security in the world, a global supplier of cereals and oilseeds, organic products and poultry and eggs. Export positions of corn, wheat and barley to the markets of Africa, India and China are changing. We have the opportunity to obtain our own cheap raw materials for flour production and to become the main supplier of certain types of fresh vegetables and other crops in the EU.

Ukraine has become a major partner for countries in the Middle East and North Africa that have the money but the opportunity to grow their own quality food. Ukraine's role in supplying food to Sub-Equatorial Africa has grown significantly. Ukraine supplies environmentally friendly products to Europe. New forms of cooperation and collaboration are a clear example of business models, where ecosystems, joint programs, procurement and delivery systems, new jobs, irrigation strategy is implemented, which promotes the development of fruit and vegetable crops. Technologies and innovations change business processes in agro-industrial complex, production management is carried out by means of virtual service.

\section{Land reform as a direction of strategy construction}

Land reform is an important strategic stage in the process of historical transformation. Our country owns a quarter of the world's chernozem, 
the country has about 42 million hectares of agricultural land, annually cultivated 32 million hectares. Thanks to modernization, increasing the yield taking into account the fertility of agricultural land, Ukraine has great opportunities and is one of the three largest exporters of grain and is a world leader in such industries as soybeans and sunflower oil. Exports of domestic products are spreading to many countries around the world: China, Egypt, India, Turkey and the EU. Ukraine intends to promote food security in countries such as Qatar, Saudi Arabia and the UAE. Ukraine is one of the three largest exporters of organic products to the EU and an important step is to enter the Asian and US markets. The strategy of agro-industrial complex development includes the production of organic products, financing of agribusiness, communication with the National Bank of Ukraine to obtain loans at a favorable interest rate, production of seeds and fertilizers [1]. Therefore, assistance to small and medium-sized farms is one of the strategic directions for agricultural development. The state must provide guarantees for the modernization of infrastructure and transportation of crops to world markets (Table 1).

The state supports such areas as: livestock, compensation for the purchase of agricultural machinery, financing of farms, agricultural insurance, drought control, irrigation development, the rate of organic products, potatoes, horticulture, viticulture and hop growing (Table 2).

The state should not have reduced the amount of state support for agriculture. The consequences of insufficient financial support are already a critical situation in the livestock sector in Ukraine. So the list of programs is clear. Reimbursement of the cost of purchasing livestock and crop materials is support in the development of these areas, subsidies for new construction and reconstruction, the purchase of lines of commodity processing and processing [2].

Support for biodiversity and biological safety requires 180 million hryvnias per year and will preserve the gene pool of local and endangered breeds, ensure genetic diversity and traceability of animal movements and epizootic welfare in Ukraine (Figure 1).

Changing the structure of livestock production will increase the share of agricultural enterprises, provide resources to ensure the welfare of cattle, increase high-yielding cows, ensure domestic consumption, support the export potential of the dairy industry. The required amount of funds per year is UAH 1,770 million. 
Financing of agro-industrial complex by the state in 2021

\begin{tabular}{|c|c|c|}
\hline $\begin{array}{l}\text { Direction of } \\
\text { financing }\end{array}$ & $\begin{array}{l}\text { The amount of } \\
\text { funding }\end{array}$ & Funding criteria \\
\hline $\begin{array}{l}\text { Financial support } \\
\text { for measures in } \\
\text { the agro-industrial } \\
\text { complex by reducing } \\
\text { the cost of loans }\end{array}$ & $\begin{array}{l}\text { UAH } 1.2 \text { billion } \\
\text { (in } 2020-\text { UAH } \\
1.05 \text { billion) }\end{array}$ & $\begin{array}{l}\text { - determine a transparent procedure for selecting } \\
\text { applicants for support; } \\
\text { - clarify the use of credit funds; } \\
\text { - it is possible to receive compensation for } \\
\text { short- and medium-term loans to replenish } \\
\text { working capital (agricultural producers who } \\
\text { have suffered from weather conditions and } \\
\text { whose loans have been restructured by banks } \\
\text { will be able to receive partial compensation for } \\
\text { interest on loans); } \\
\text { - medium- and long-term loans raised for } \\
\text { the purchase of fixed assets of agricultural } \\
\text { production, the implementation of costs } \\
\text { associated with the construction and } \\
\text { reconstruction of agricultural production } \\
\text { facilities, as well as the processing of } \\
\text { agricultural products; } \\
\text { - determine the deadlines for submission of } \\
\text { applications by entities for compensation } \\
\text { and registers of compensation payments to } \\
\text { borrowers, which are submitted to the Ministry } \\
\text { of Economy by authorized banks (annually until } \\
\text { November 1). }\end{array}$ \\
\hline $\begin{array}{l}\text { State support for } \\
\text { the development of } \\
\text { animal husbandry } \\
\text { and processing of } \\
\text { agricultural products }\end{array}$ & $\begin{array}{l}\text { UAH } 1,150.0 \\
\text { billion (UAH } \\
1,039.1 \text { billion in } \\
2020) \text {. }\end{array}$ & $\begin{array}{l}\text { - Support for farmers (subsidies for keeping } \\
\text { cows) - UAH } 100 \text { million (in } 2020 \text { - UAH } \\
35.14 \text { million); } \\
\text { - Reimbursement of the cost of purchased } \\
\text { breeding animals and embryos amounted to UAH } \\
350 \text { million (in } 2020 \text { - UAH } 300 \text { million); } \\
\text { - Special budget subsidy for existing bee } \\
\text { colonies - UAH } 327.07 \text { million (in } 2020-\text { UAH } \\
239.8 \text { million); }\end{array}$ \\
\hline $\begin{array}{l}\text { Partial compensation } \\
\text { for the cost of } \\
\text { agricultural machinery }\end{array}$ & $\begin{array}{l}\text { UAH } 1 \text { billion } \\
\text { (UAH } 892.6 \\
\text { million in } 2020 \text { ) }\end{array}$ & $\begin{array}{l}320 \text { new items of machinery and equipment } \\
\text { have been added to the list, of which there are } \\
\text { now } 14,892 \text { from } 200 \text { manufacturers. The list of } \\
\text { manufacturing plants also increased by } 9 \text {. }\end{array}$ \\
\hline $\begin{array}{l}\text { Financial support } \\
\text { for the development } \\
\text { of viticulture, } \\
\text { horticulture and hop } \\
\text { growing }\end{array}$ & $\begin{array}{l}\text { UAH } 450 \text { million } \\
\text { (in } 2020 \text { - UAH } \\
290 \text { million) }\end{array}$ & $\begin{array}{l}\text { - purchase of planting material - up to } 80 \% \text {; } \\
\text { - construction of wallpaper and installation of } \\
\text { drip irrigation systems - up to } 50 \% \text {; } \\
\text { - new construction and reconstruction of } \\
\text { refrigerators, processing plants and product } \\
\text { freezing facilities - up to } 50 \% \text {; } \\
\text { - purchase of technological lines for commodity } \\
\text { processing and product processing - up to } 50 \% \text {; } \\
\text { - purchase of machinery, mechanisms and } \\
\text { equipment (including foreign) - up to } 30 \% \text {. }\end{array}$ \\
\hline
\end{tabular}


Table 2

The general structure of state support programs for 2021

\begin{tabular}{|c|c|c|c|}
\hline Program & $\begin{array}{l}\text { Volume of } \\
\text { state aid, } \\
\text { UAH million }\end{array}$ & $\begin{array}{c}\text { Number } \\
\text { of jobs per } \\
\text { UAH } \\
1 \text { million of } \\
\text { state aid } \\
\end{array}$ & $\begin{array}{l}\text { Number of } \\
\text { jobs created }\end{array}$ \\
\hline $\begin{array}{l}\text { Partial compensation of the cost of } \\
\text { agricultural machinery of domestic } \\
\text { production }\end{array}$ & 1000 & 1 & 1000 \\
\hline $\begin{array}{l}\text { Financial support for measures in the } \\
\text { agro-industrial complex by reducing } \\
\text { the cost of loans for } 2021\end{array}$ & 1200 & 8 & 9600 \\
\hline $\begin{array}{l}\text { Financial support for horticulture, } \\
\text { viticulture and hop growing }\end{array}$ & 450 & 20 & 9000 \\
\hline Subsidy per unit of arable land & 60 & 20 & 1200 \\
\hline Subsidy for keeping cows & 100 & 40 & 4000 \\
\hline $\begin{array}{l}\text { Partial reimbursement of costs for } \\
\text { advisory services provided }\end{array}$ & 15 & 6 & 90 \\
\hline $\begin{array}{l}\text { Surcharge in favor of insured persons } \\
\text { - members / chairman of SFG SSC }\end{array}$ & 25 & 50 & 1250 \\
\hline $\begin{array}{l}\text { Reimbursement of purchased breeding } \\
\text { animals, bees, semen and embryos up } \\
\text { to } 50 \% \text { of the cost }\end{array}$ & 350 & 1,5 & 525 \\
\hline $\begin{array}{l}\text { Special budget subsidy if there is a bee } \\
\text { family }\end{array}$ & 240 & 15 & 3600 \\
\hline $\begin{array}{l}\text { Reimbursement of livestock facilities } \\
\text { (up to } 50 \% \text { of the cost) }\end{array}$ & 350 & 2 & 700 \\
\hline $\begin{array}{l}\text { Reimbursement of the value of objects } \\
\text { financed by bank loans }\end{array}$ & 60 & 1 & 60 \\
\hline $\begin{array}{l}\text { Special budget subsidy for keeping } \\
\text { goats, goats, ewes, ewes }\end{array}$ & 50 & 1,5 & 75 \\
\hline $\begin{array}{l}\text { Special budget subsidy for the growth } \\
\text { of self-breeding cows }\end{array}$ & 100 & 1,5 & 150 \\
\hline State support for agricultural insurance & 240 & - & - \\
\hline Support for organic production & 100 & 10 & 1000 \\
\hline $\begin{array}{l}\text { State support for the development of } \\
\text { potato growing }\end{array}$ & 60 & 9 & 540 \\
\hline State support for irrigation & 100 & - & - \\
\hline TOTAL & 4500 & 12,4 & 32790 \\
\hline
\end{tabular}




\begin{tabular}{|c|c|}
\hline \multicolumn{2}{|c|}{ Farms } \\
\hline$\sqrt{7}$ & $\nabla$ \\
\hline Financial support of the state & Result \\
\hline $\begin{array}{l}\text { - Financial support of } \\
\text { agricultural service } \\
\text { cooperatives through partial } \\
\text { compensation of the cost of } \\
\text { domestic machinery and } \\
\text { equipment purchased for own } \\
\text { and on credit; } \\
\text { - Partial reimbursement of } \\
\text { costs related to the provision of } \\
\text { agricultural advisory services. }\end{array}$ & $\begin{array}{l}\text { - The amount of support for } \\
1 \text { cooperative is not more than } \\
\text { UAH } 3 \text { million. With state } \\
\text { support, cooperatives will be } \\
\text { able to purchase machinery and } \\
\text { equipment and build facilities } \\
\text { for processing and storing } \\
\text { agricultural products; } \\
\text { - Direct support will encourage } \\
\text { the establishment of qualified } \\
\text { agricultural advisory services } \\
\text { and provide professional advice } \\
\text { on agricultural activities. }\end{array}$ \\
\hline
\end{tabular}

\section{Figure 1. State support of farms}

Regarding the production of value added products, it should be noted that such production will increase the share of the organized sector by $15 \%$, by $10 \%$ of sheep and goats annually, provide fattening of sheep and goats to high weight conditions, provide resources to ensure traceability in beekeeping, will support the export potential of honey and lamb (Table 3).

\section{Development of economic strategy for agro-industrial complex}

The budget subsidy per unit of arable land to newly established farms will increase the amount of support from the state, taking into account the increase in the cost of logistics and inflation and will support the young head of the farm (up to 35 years), which will enable rural youth to realize their benefits. in this direction and will help stop migration from rural areas. If the state budget provides funds in the amount of UAH 120 million over 3 years, the 
Kateryna Malinoshevska

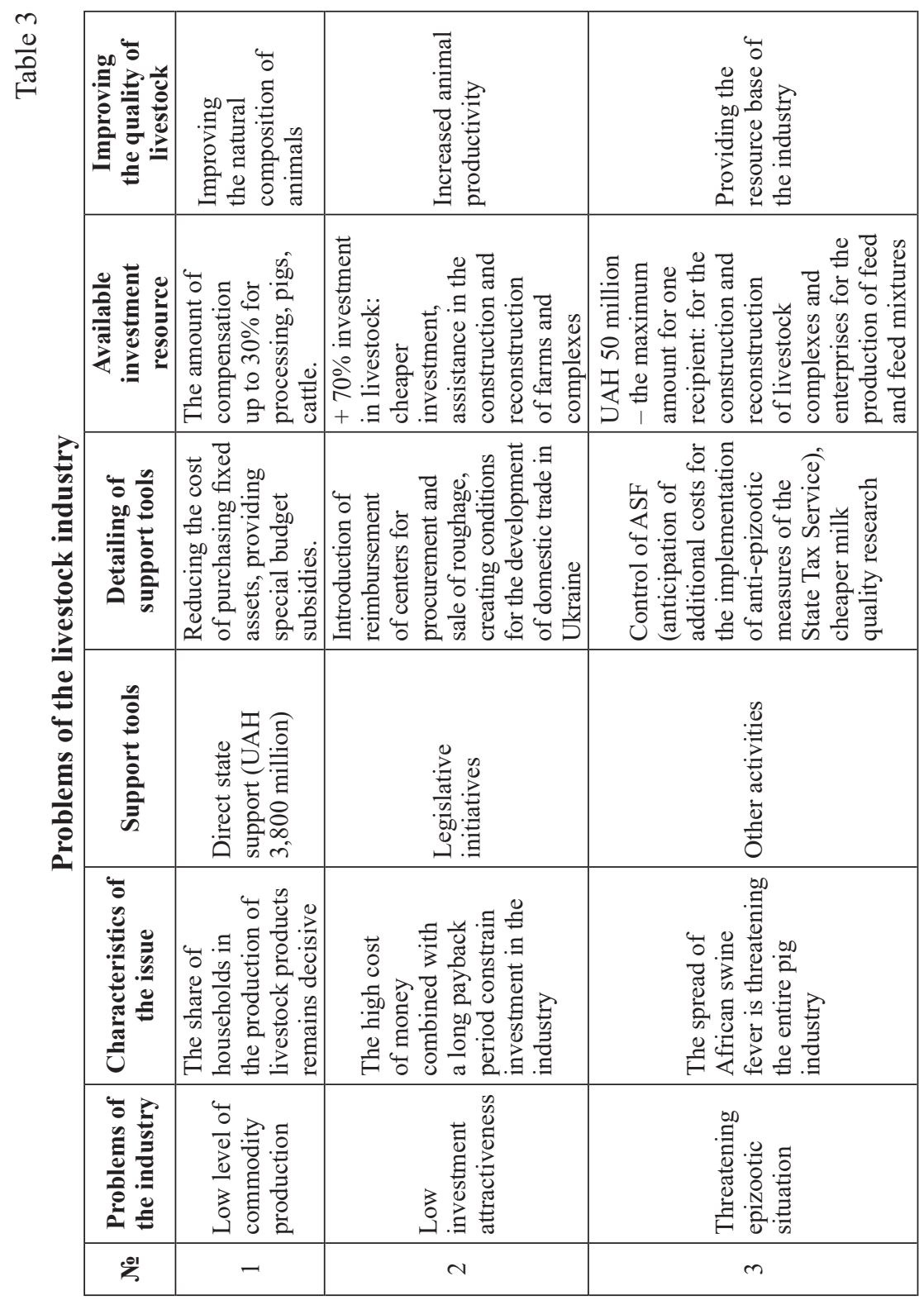




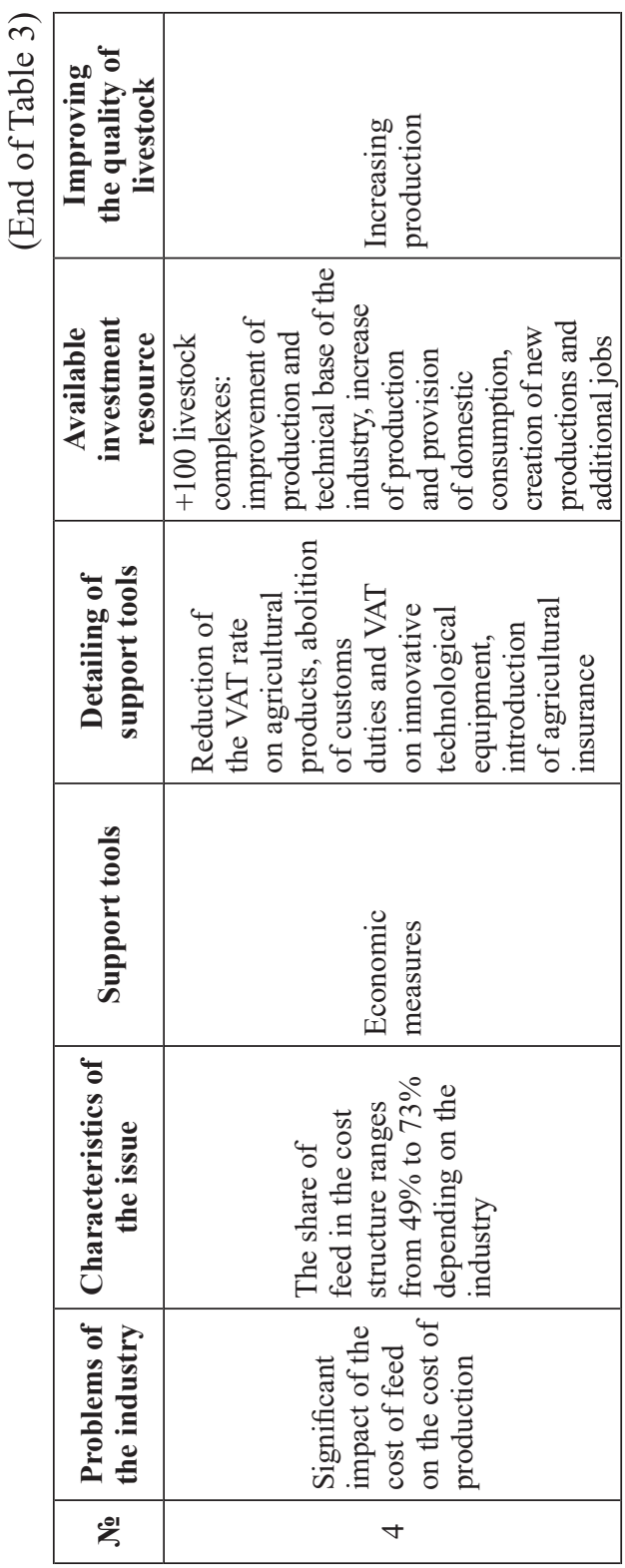

need for financial resources of 2,000 newly established farms will be met. A special budget subsidy for keeping dairy cows will support livestock through such a subsidy and will help increase the number of dairy cows and improve the quality of milk produced [3]. Regarding financial support on a repayable basis: interest-free loans, expanding the range of recipients will help upgrade the material and technical base and development of farms, implement business initiatives and projects to build value chains. The development of organic production will enable about 300 farms to benefit from state financial support, partially offset the costs of farms associated with the certification of organic production, reduce the cost of purchasing permitted plant protection products and fertilizers (Table 4).

The agro-industrial complex has an investment priority, in 2020 there was an investment decline, this is due to insufficiently justified changes in macroeconomic 
Development of economic strategy for agro-industrial complex

\begin{tabular}{|c|c|}
\hline Strategic direction & Characteristic \\
\hline $\begin{array}{l}\text { Ensuring effective regulation } \\
\text { for long-term sustainable } \\
\text { development of the } \\
\text { agricultural sector. }\end{array}$ & $\begin{array}{l}\text { Ensuring the implementation of effective state policy, } \\
\text { reforming the State Geocadastre, development of the } \\
\text { land market and decentralization of land relations, or } \\
\text { promoting long-term sustainable development of the } \\
\text { agricultural sector and rural areas. }\end{array}$ \\
\hline $\begin{array}{l}\text { Development of irrigation and } \\
\text { drainage systems to increase } \\
\text { crop yields. }\end{array}$ & $\begin{array}{l}\text { The priority is to create preconditions for investment } \\
\text { in the irrigation and drainage system, in the } \\
\text { regulation of legislation in the field. This will } \\
\text { increase the yield of Ukrainian agricultural lands and } \\
\text { incomes of agricultural producers. }\end{array}$ \\
\hline $\begin{array}{l}\text { Stimulating the implementation } \\
\text { of Agtech to improve } \\
\text { productivity and optimize the } \\
\text { costs of agricultural producers. }\end{array}$ & $\begin{array}{l}\text { Encouraging the use of high technology will } \\
\text { significantly increase productivity in the sector } \\
\text { and reduce costs for businesses, increasing their } \\
\text { competitiveness. }\end{array}$ \\
\hline $\begin{array}{l}\text { Increasing the production of } \\
\text { high-margin crops to increase } \\
\text { value added in the agricultural } \\
\text { sector. }\end{array}$ & $\begin{array}{l}\text { High-margin crops account for only } 11 \% \text { of the total } \\
\text { crop structure in Ukraine, which is much lower than } \\
\text { in the EU. The key task is to change the Ukrainian } \\
\text { crop mix with an increase in the share of vegetables, } \\
\text { fruits and berries, which will have a positive } \\
\text { impact on the value added created in the Ukrainian } \\
\text { agricultural sector. }\end{array}$ \\
\hline $\begin{array}{l}\text { Expansion of elevator } \\
\text { capacities to reduce losses of } \\
\text { agricultural products. }\end{array}$ & $\begin{array}{l}\text { The total capacity of granaries in Ukraine does } \\
\text { not meet the existing demand, as well as unevenly } \\
\text { distributed throughout the country. The state's } \\
\text { focus should be on expanding the capacity to store } \\
\text { agricultural products, which will reduce product } \\
\text { losses and increase production. }\end{array}$ \\
\hline $\begin{array}{l}\text { Stimulating the processing } \\
\text { of agricultural products to } \\
\text { increase the added value. }\end{array}$ & $\begin{array}{l}\text { Providing up-to-date information on the prospects } \\
\text { and opportunities for product processing and } \\
\text { compensation of costs associated with the creation of } \\
\text { processing facilities will reveal the export potential } \\
\text { of Ukrainian producers and will have a positive } \\
\text { impact on the country's economy. }\end{array}$ \\
\hline $\begin{array}{l}\text { Providing a skilled workforce } \\
\text { that meets the needs of the } \\
\text { agricultural sector. }\end{array}$ & $\begin{array}{l}\text { A necessary step is the development of self- } \\
\text { employment and the improvement of the well-being } \\
\text { of the rural population. In addition, the development } \\
\text { of dual education in the agricultural sector will have } \\
\text { a positive impact on the level of skills of workers in } \\
\text { the industry. }\end{array}$ \\
\hline
\end{tabular}


(End of Table 4)

\begin{tabular}{|l|l|}
\hline \multicolumn{1}{|c|}{ Strategic direction } & \multicolumn{1}{c|}{ Characteristic } \\
\hline $\begin{array}{l}\text { Improving transport and } \\
\text { infrastructure to increase the } \\
\text { competitiveness of Ukrainian } \\
\text { producers. }\end{array}$ & $\begin{array}{l}\text { Underdeveloped transport infrastructure, lack of } \\
\text { timely capacity upgrades, economically unjustified } \\
\text { tariffs and insufficient capital investment in freight } \\
\text { transport create unfavorable conditions for the } \\
\text { agricultural sector. Optimization of UZ tariffs and } \\
\text { AMCU fees, improvement of corporate governance, } \\
\text { as well as expansion and provision of financing } \\
\text { of capital investment plans will improve the } \\
\text { competitiveness of Ukrainian producers. }\end{array}$ \\
\hline $\begin{array}{l}\text { Providing access to markets } \\
\text { for small and medium } \\
\text { agricultural producers. }\end{array}$ & $\begin{array}{l}\text { An important task is to ensure access of all } \\
\text { agricultural producers to markets, including by } \\
\text { intensifying cooperation between producers and the } \\
\text { development of clusters. }\end{array}$ \\
\hline $\begin{array}{l}\text { Harmonization of Ukrainian } \\
\text { legislation with the EU to } \\
\text { expand access of Ukrainian } \\
\text { enterprises to the European } \\
\text { market. }\end{array}$ & $\begin{array}{l}\text { Alignment of Ukrainian legislation with EU trade } \\
\text { directives and regulations will open access to } \\
\text { European markets for Ukrainian producers and will } \\
\text { have an overall positive impact on the country's } \\
\text { economy in the context of removing trade barriers } \\
\text { and, consequently, increasing exports. }\end{array}$ \\
\hline
\end{tabular}

management of agri-food sectors of the economy, unfavorable climatic conditions in agriculture, the COVID-19 pandemic, the refusal of agribusiness to implement investment projects. due to their expectations for the purchase of agricultural land, reducing the amount of state financial support for agricultural producers, deteriorating conditions of small business, increasing risks of investment and preservation of capital. Therefore, the development of the agricultural sector is a priority today: the opening and liberalization of the land market, improving reclamation infrastructure and improving the quality and safety of food [4].

The most important step in developing an effective quality management strategy is strategic analysis, which provides a realistic assessment of their own resources and capabilities in relation to the state and needs of the external environment. Based on this analysis, there is a rational choice of strategies from a possible set of options. One of the tools of regular strategic management is a matrix of qualitative strategic analysis, which we propose to build using methodological approaches to building a matrix of SWOTanalysis (strengths - strengths, weaknesses - weaknesses, opportunities - 
opportunities, threats - threats). The analysis methodology based on the use of the matrix of qualitative strategic analysis involves the priority identification of strengths and weaknesses, potential opportunities and threats and further establishment of relationships between them that can be used to formulate the strategy of the organization.

At the initial stage of the analysis, a list of strengths (and weaknesses), as well as threats and opportunities of the organization, taking into account the current situation.

In the general case, the information to be obtained during the qualitative strategic analysis in our case can be presented in the form of a matrix (table 5).

The harvest insurance program provided by law is an important component of financial security for agricultural enterprises. The state crop insurance program is periodic and is adjusted based on risk assessments. Harvest insurance allows farms to control production and operational processes due to bad weather conditions and other negative factors. Beginner farmers are a fundamental factor in the growth of the agricultural market, so young professionals need to be encouraged, supported and developed financially sustainable operations to promote new generations of farmers. Rural prosperity is achieved by providing safe working conditions for domestic agricultural enterprises and improving the implementation of state support programs. Internal evaluation of the effectiveness of achieving strategies provides effective financing and creates protection for agricultural enterprises, provides jobs [6].

Quality locally or regionally produced products focus on improving access to organic food, spreading to traditional and non-traditional retail options where producers have access to market information, making the right management decisions by developing systems and portals, developing quality standards and promoting world trade. .

The strategy of plant protection begins with the detection of pests and diseases with high risks, constant monitoring of their occurrence. Therefore, when importing agricultural products, it is necessary to carefully check the spread of the disease, which can lead to significant costs for domestic producers and consumers. Detection of such negative factors or emergency situation requires a rapid response from the state and requires the development of threats, surveillance, monitoring 
tools - to identify, diagnose through a network of laboratories with highly qualified government personnel [7]. The measure of the effectiveness of the strategy for the protection of livestock and crop production is the assessment of new threats, problems and opportunities, the creation of working groups for further research and modification of practical skills, scheduled meetings with management to obtain feedback and initiatives to develop strategies: creating a system of competitive agriculture to identify marketing trends.

\section{Conclusions}

The development of the agro-industrial complex is influenced by the negative consequences of coronavirus infection, which reduces the export of agricultural products. It should be noted that the development of agroindustrial complex is related to the quality of life of the rural population and requires the improvement of transport, engineering and social infrastructure. The developed structure of the agro-industrial complex is important for the welfare of the economy as a whole. Reliable food is provided by agricultural holdings and farms, support the growth of jobs in rural areas, the competitiveness of agriculture. Highly productive animals and plants will increase the efficiency of the agro-industrial complex on a practical level, provide high positions in the growth of the agricultural market: ensure effective financial security, support for viable agriculture, production and support of jobs and economic growth. Understanding customer needs is essential for quality service. Assessing the experience of farms and their interaction with customers will provide a better understanding of consumer expectations, identify projects that have the greatest impact on customers and develop performance indicators. The analysis of such indicators will allow to determine investment priorities, to improve clients' access to risk management programs through highly qualified employees.

A competitive agricultural system is not possible without increasing agricultural opportunities, supporting economic growth and creating new markets. Departments and services of the agro-industrial complex provide sectoral services to help agriculture, food producers and enterprises that create and improve the agricultural system. Evaluation, design, planning of food producers is associated with improving the efficiency of permanent 


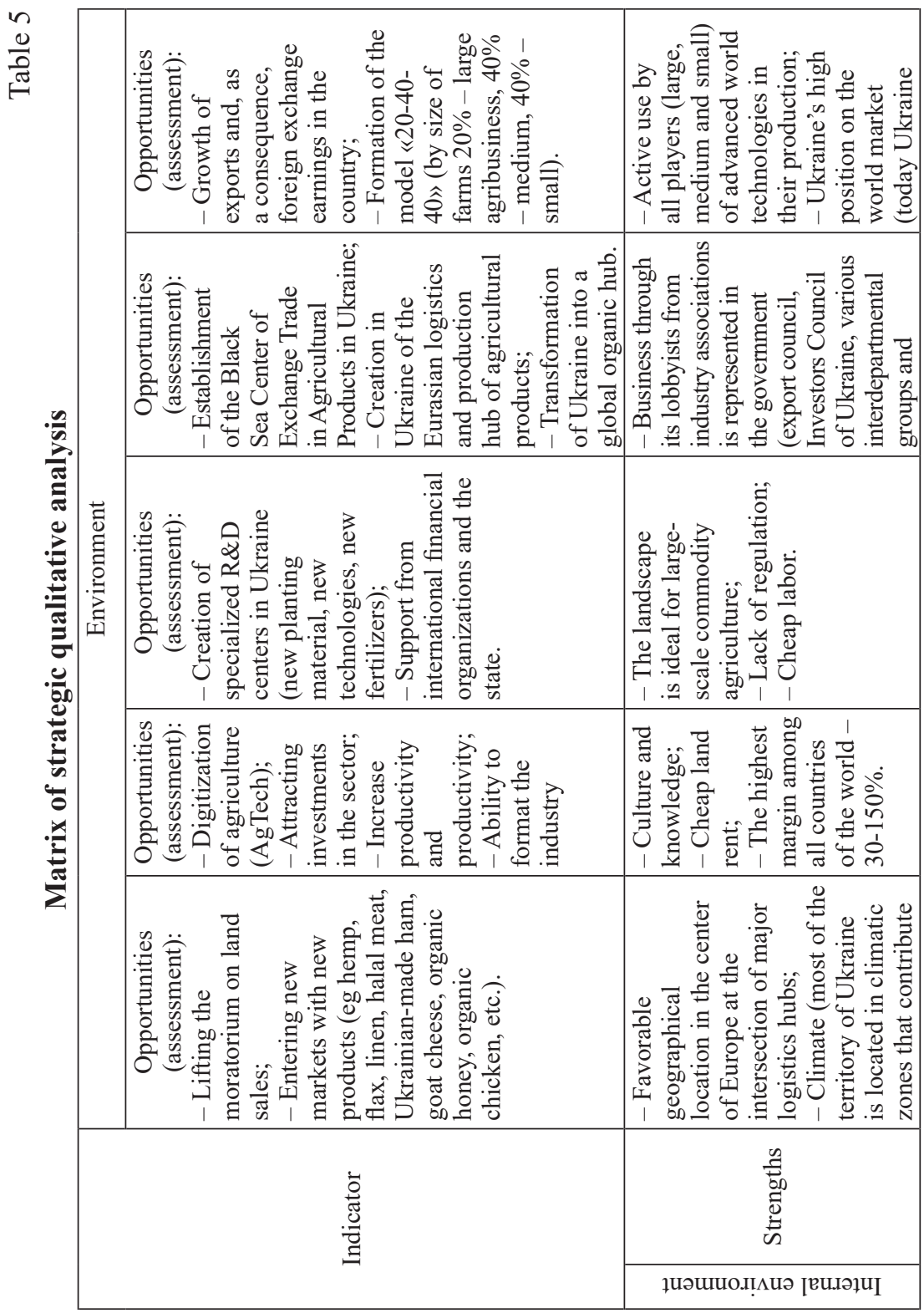




\begin{tabular}{|c|c|}
\hline 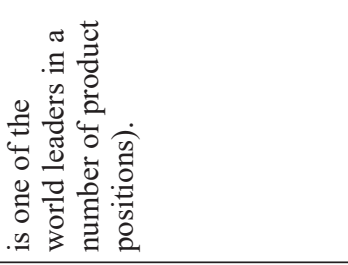 & 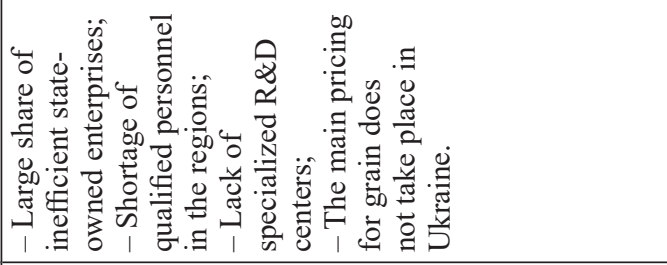 \\
\hline \multirow[t]{3}{*}{ 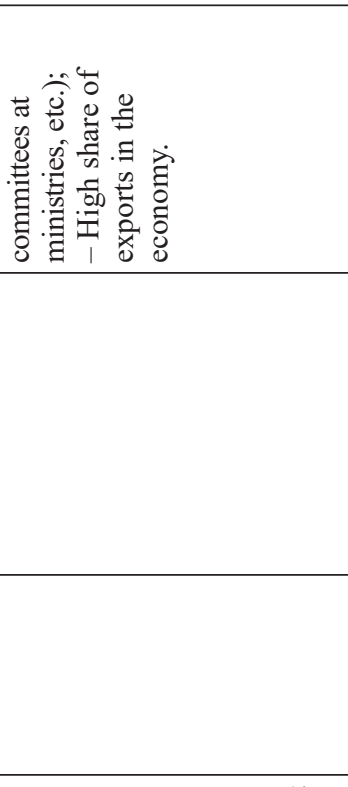 } & 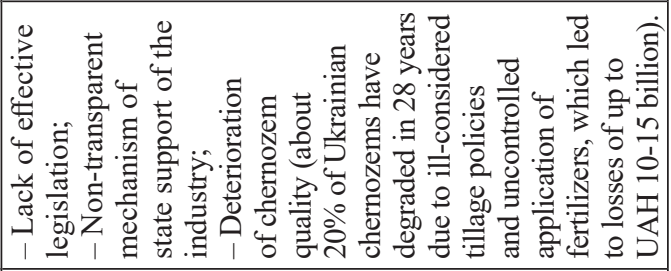 \\
\hline & 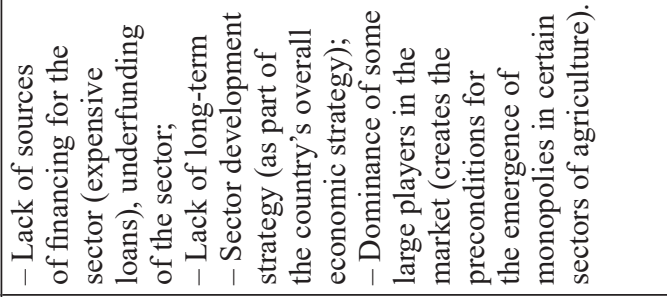 \\
\hline & 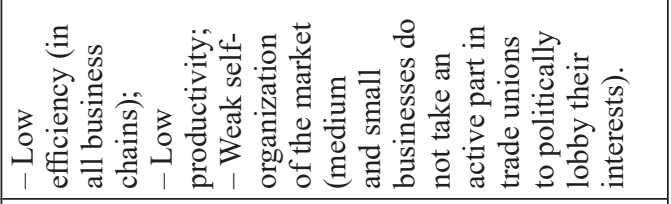 \\
\hline 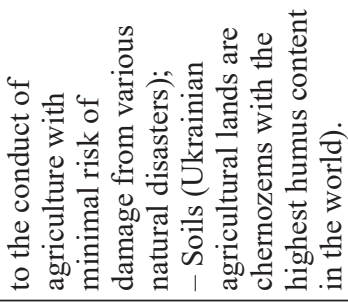 & 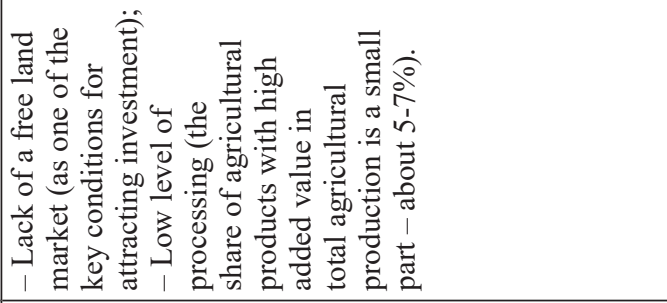 \\
\hline 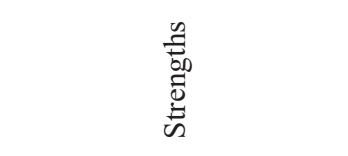 & 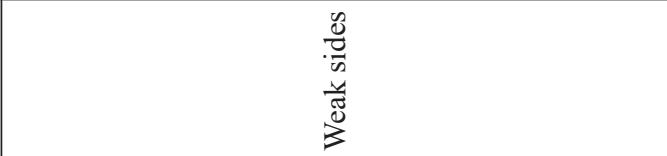 \\
\hline 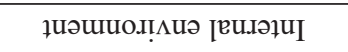 & \\
\hline
\end{tabular}


food market facilities and stakeholders. These facilities include wholesale markets, farmers' markets, government markets and food centers, all of which are important parts of the national food distribution network and provide important agricultural opportunities for producers.

Government programs aim to support domestic producers, local and regional food systems, innovative methodologies and marketing strategies, including expanded access to fruits and vegetables, transport, food security and sustainability. It is necessary to expand new markets for agricultural products because the demand for agricultural products is growing, so the programs have tools to meet the current and future needs of consumers and producers. The creation and expansion of markets is impossible without training, creating a service project, evaluating the activities of agricultural enterprises and improving the efficiency of food systems and the food market. Developing and maintaining markets for domestic producers is a very important step, using innovative methods to gather information, the state should modernize and restructure agricultural services programs that meet customer needs and take advantage of opportunities to achieve greater efficiency through simplified processes in the agricultural market. Market transparency and free access to food develop market opportunities, forming communication links between consumers and agricultural enterprises. Through industry specifications, domestic agricultural producers have the opportunity to create and improve the quality of production, trying to comply with quality standards, market analysis and product integrity. Research, food security, market access for agro-industrial products, improving the efficiency of distribution systems are important areas for stakeholders and the food supply chain as a whole.

The expansion of international marketing and export of products is of crucial importance for domestic agro-industrial enterprises. Promotion of agricultural products on world markets through promotional activities, development of international standards, compliance with trade agreements that will promote cooperation with developing countries and developed countries. Long-term international relations are the basis for building future markets and will contribute to the further development of the country's agro-industrial complex. By removing barriers to agricultural exports and building the potential to increase export demand. 


\section{References:}

1. United Nations (2013) Trade and development report 2013. United nations conference on trade and development. New York, Geneva: United Nations.

2. Laczko, F., \& Gozdziak, E. M. (2006) Migration for Development: Within and Beyond Frontiers.

3. Mazzucato, V., Van Den Boom, B., \& Nsowah-Nuamah, N.N. (2008) Remittances in Ghana: Origin, destination and issues of measurement. International Migration, no. 46(1), pp. 103-122.

4. Hlushkova T.V. Innovation Components of the Modern Advertisement [Online]. Available at: http://nbuv.gov.ua/UJRN/apmk_2013_14_31 (accessed on February 15, 2021).

5. Vovk I.P. (2012) Osoblyvosti vprovadzhennia zakhodiv resursozberezhennia ta metodyka vyznachennia yikh efektyvnosti na mashynobudivnykh pidpryiemstvakh v konteksti resursonomiky [Features of resource conservation measures and methods of their effectiveness in engineering enterprises in the context of resourcenomy]. Visnyk of Sumy State University. Economics Series, no. 4, pp. $107-117$.

6. Official Website of the Analytical Agency Business Views [Online]. Available at: http://businessviews.com.ua/ (accessed on February 10, 2021).

7. Mazaraki A.A., Melnyk T.M., Chaiun T.I. (2000) International Marketing: Textbook for Students of HEI. Kyiv: KNTEU, 306 p. 